\title{
Mogan Gölü balık faunası
}

\author{
Ali GÜL ${ }^{1, *}$, Semra BENZER ${ }^{2}$, Ömer SAYLAR ${ }^{2}$, Göktuğ GÜL ${ }^{3}$, Mehmet YILMAZ ${ }^{1}$ \\ ${ }^{1}$ Gazi Üniversitesi, Gazi Ĕgitim Fakültesi, Biyoloji Eğitimi Anabilim Dalı, Ankara \\ ${ }^{2}$ Gazi Üniversitesi, Gazi Eğitim Fakültesi, Fen Bilgisi Eğitimi Anabilim Dal, Ankara \\ ${ }^{3}$ Gazi Üniversitesi, Sağlık Hizmetleri Meslek Yüksekokulu, Gölbaşı, Ankara
}

Gelis Tarihi (Recived Date): 07.03.2017

Kabul Tarihi (Accepted Date): 12.05.2017

\section{Özet}

Bu çalışma, Ankara'nın güneyinde tektonik bir göl olan Mogan Gölü’ndeki balık türlerinin tespiti amacıyla gerçekleştirilmiştir. Balık örnekleri gölün farklı alanlarından Ocak-Aralık 2014 tarihleri arasında kepçe, olta, elektroşoker ve çeşitli göz açıklı̆̆ına sahip ăglar kullanılarak yakalanmıştır. Avlanan balık örnekleri \%4'lük formaldehit içinde laboratuvara getirilerek metrik ve meristik özellikleri belirlenmiştir. Cyprinidae, Atherinidae ve Esocidae familyalarina ait sirasiyla Cyprinus carpio, Carassius gibelio, Tinca tinca, Alburnus escherichii, Pseudorasbora parva, Atherina boyeri ve Esox lucius tespit edilmiştir. Çalışmada, gölde bulunduğu literatürde bildirilen Silurus glanis'e rastlanmamıştır. Göle giriş şekli belirlenemeyen istilacı türlerden Carassius gibelio, Pseudorasbora parva ve Atherina boyeri'nin diğer türler üzerindeki olast etkileri ve popülasyonların geleceği için biyo-ekolojik izleme çalışmalarının yapılması yararlı olacaktır.

Anahtar Kelimeler: Mogan Gölü, balık, fauna, morfomeristik karakterler

\section{Fish fauna in Mogan Lake}

\begin{abstract}
\footnotetext{
*Ali GÜL, aligul@gazi.edu.tr, http://orcid.org/0000-0001-5751-4705

Semra BENZER, sbenzer@gmail.com, http://orcid.org/0000-0002-8548-8994

Ömer SAYLAR, osaylar@gazi.edu.tr, http://orcid.org/0000-0002-6837-2981

Göktuğ GÜL, goktuggul@gazi.edu.tr, http://orcid.org/0000-0003-1925-0803

Mehmet YILMAZ, myilmaz@gazi.edu.tr, http://orcid.org/0000-0001-6700-6579
}

This study was carried out for a determination of the fish fauna of a tectonic Mogan Lake where was located at the south of Ankara Province. The fish species were captured by use of fishing rods, electroshocker, and nets with various mesh sizes from the different regions of the lake between January and December 2014. The captured 
fish samples were kept in 4\% of formaldehyde and brought to the laboratory to determine their meristic and metric features. Cyprinus carpio, Carassius gibelio, Tinca tinca, Alburnus escherichii, Pseudorasbora parva, Atherina boyeri, and Esox lucius belonging to Cyprinidae, Atherinidae and Esocidae, respectively were determined. In this study, the Silurus glanis reported in the literature was not encountered. There are invasive species such as Carassius gibelio, Pseudorasbora parva and Atherina boyeri with unknown introduction in the lake. In order to determine of the possible effects of these species upon the population of other species in the lake further bio-ecologic studies are needed.

Keywords: Mogan Lake, fish, fauna, morphomeristic characters

\section{Giriş}

Balıkların biyolojik özellikleri kapsamında morfometrik ve meristik özelliklerinin farklı su sistemlerinde belirlenmesi, ihtiyofauna açısından önemlidir. Balık populasyonları üzerinde yapılan çalışmalar evrim, ekoloji, davranış, koruma, su kaynakları yönetimi ve stok değerlendirmesi dahil çeşitli bakış açılarından değerlendirilmelidir [1]. Balıklarda yapılan morfometrik ve meristik ölçümler, bir sulak alanın faunasının ve biyolojik çeşitliliğinin belirlenmesinde önemli olup, balık populasyonlarında morfolojik farklılaşmanın olup olmadığını da ortaya koyar.

Türkiye iç suları endemik, egzotik ve ekonomik karakterli çok sayıda balık türü barındırmaktadır. Bir ekosistemdeki balık faunasını belirlemek ve tür içindeki farklılıkları tespit etmek için balık taksonlarının morfometrik ve meristik ölçümlerinin yapılmas1 gerekir [2].

Türkiye'de tatlısu balık faunası ile ilgili ilk çalışmanın Abbolt tarafından 1835 yılında yapıldığı bildirilmektedir [3]. Sonraki yıllarda çeşitli su sistemlerinde balık faunasının tespiti ve biyolojik özelliklerini belirleme çalışmaları devam etmiştir. Türkiye iç sularında 31 familyaya ait 377 balık türü bulunduğu bildirilmektedir [4, 5]. Bu türlerden \%51.1'inin (188 tür) Cyprinidae familyasına ait olduğu, \%41.58'inin de (157 tür) endemik olduğu belirtilmektedir [5].

Mogan Gölü Ankara'nın güneyinde bulunan bir tatlı su gölüdür. Çevresinde çok sayıda sosyal mekan, park ve tesis bulunması, gölü Ankara'nın önemli bir rekreasyon alanı haline getirmiştir. Yaz aylarında göl yüzey alanının \% 70-80'ini tamamen makrofitler kaplamaktadır. Gölün yakın mesafedeki Eymir Gölü'ne bir bağlantı ile su sirkülasyonu olmaktadır. Gölün kuzeybatı ve güney kıyılarında bazı mevsimlerde batık makrofit hâkimiyeti oluşmaktadır. Bu durumdan balık populasyonları ve stoklarının önemli düzeyde etkilendiği bildirilmektedir. Göl ve çevresi belirli mevsimlerde çok sayıda kuş türüne ev sahipliği yapan önemli bir sulak alan özelliğindedir [6]. Floristik ve faunistik açıdan da zengin bir yapıda olan gölde özellikle balık türlerinin çeşitli biyolojik özellikleri ve çevresel kirleticilerin etkilerine dayalı araştırmaların yapıldı̆̆ bilinmektedir [6, 7]. Gölde 2000 yılının ortalarına kadar Esox lucius'un baskın olduğu, bu yıllarda Silurus glanis'in de bulunduğu, sonraki yıllarda Cyprinus carpio ve Tinca tinca'nın en bol türler olduğu, Alburnus escherichii'nin de avlandığı belirtilmektedir [7]. 
Son yıllarda istenmeden sucul ortamlara karışan bazı egzotik türler biyolojik kirliliğe ve doğal ekosistemlerde geri dönüşümü olmayan etkilere neden olmaktadır. Pseudorasbora parva ve Atherina boyeri ülkemizde göl ve akarsulara istenmeden karışarak hızla yayılmaktadır. Öriyök karakterli Carassius türleri bulundukları ortama kısa sürede uyum göstermekte ve aşırı çoğalma eğilimi ile ortamda baskın tür haline gelmektedirler. Asya kökenli olan Carassius gibelio da çeşitli yollarla Avrupa ülkeleri ve Türkiye'de hızla yayılmaktadır. Türkiye iç sularına doğal yollarla girmediği ve doğal balık toplulukları için zararlı bir tür olduğu bilinmektedir [5]. Bu nedenle, yerli türler ile istilacı türlerin birlikte bulunduğu Mogan Gölü balık faunası araştırmaya değer görülmüştür. Mogan Gölü’nde farklı araştırıcılar balık türlerinin çeşitli özelliklerini araştırmış ve gölden farklı tarihlerde balık türlerinin kayıtları verilmiştir [8-15].

Farklı su sistemlerinde balıkların morfometrik ve meristik özelliklerinin belirlenmesi, stokların tespiti açısından önemlidir. Bir sulak alanda ihtiyofaunanın ortaya konulabilmesi için tüm balık türlerinin biyolojik özelliklerinin bilinmesi ve periyodik izleme çalışmalarının yapılması gerekmektedir. Bu nedenle Mogan Gölü’ndeki balık türlerinin saptanarak morfometrik ve meristik özelliklerinin verilmesi amaçlanmıştır.

\section{Materyal ve metot}

Mogan Gölü Ankara'nın güneyinde $39^{\circ} 47^{\prime} 56^{\prime \prime} \mathrm{N}$ ve $32^{\circ} 47^{\prime} 4^{\prime \prime}$ E boylamları arasında $960 \mathrm{~m}$ rakımında tektonik bir göldür. Gölün uzunluğu $6 \mathrm{~km}$, eni $900 \mathrm{~m}$, ortalama derinliği 3.5-4 m, göl alanı $63 \mathrm{~km}^{2}$ ve hacmi 13-14 milyon $\mathrm{m}^{3}$ 'ür [6, 7] (Şekil 1). Çalışma Ocak-Aralık 2014 tarihleri arasında göl ve göle dökülen Gerger ve Eymir derelerinde gerçekleştirilmiştir. Balıkların avlanmasında kepçe, olta, elektroşoker ve çeşitli göz açıklığına sahip ağlar kullanılmıştır. Balık örneklerinin teşhislerinde çeşitli çalışmalardan yararlanılmıştır [3, 5, 16-20]. Örneklerin fotoğrafları çekilmiş ve metrik özelliklerden standart boy (SB), vücut yüksekliği (VY), baş boyu (BB), göz çap1 (GÇ) ve interorbital mesafe (IM) mm olarak ölçülmüştür. Meristik özelliklerden, dorsal yüzgeç (D), anal yüzgeç (A), pektoral yüzgeç (P), ventral yüzgeç (V) 1şın sayıları, Line lateral pul sayısı (L. lat.) ve omur sayıları tespit edilmiştir.

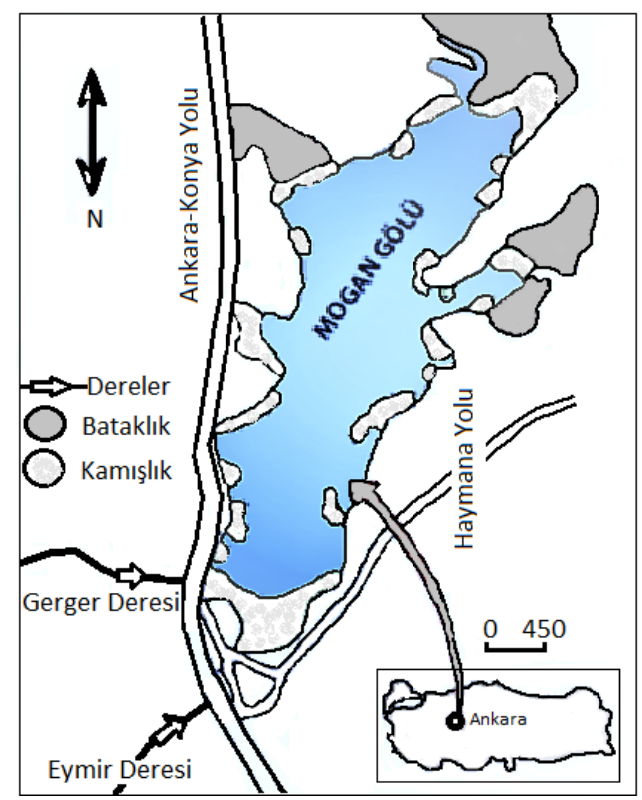


Şekil 1. Mogan Gölü haritası

\section{Bulgular}

\section{1. Çalışma alanından belirlenen balık türleri}

$\mathrm{Bu}$ çalışmada Cyprinidae familyasından Cyprinus carpio L. 1758, Carassius gibelio (Bloch, 1782), Tinca tinca (L. 1758), Alburnus escherichii Steindachner, 1897, Pseudorasbora parva (Temminck ve Schlegel, 1846); Atherinidae familyasindan Atherina boyeri Risso, 1810 ve Esocidae familyasından, Esox lucius L. 1758 olmak üzere 3 familyaya ait 7 tür tespit edilmiş ve türlere ait bazı diyagnostik özellikler saptanmıştır.

\section{Phylum: Chordata}

Subphylum: Vertebrata

Class: Osteichthyes

Order: Cypriniformes

Family: Cyprinidae

\subsubsection{Cyprinus carpio L. 1758 (Şekil 2)}

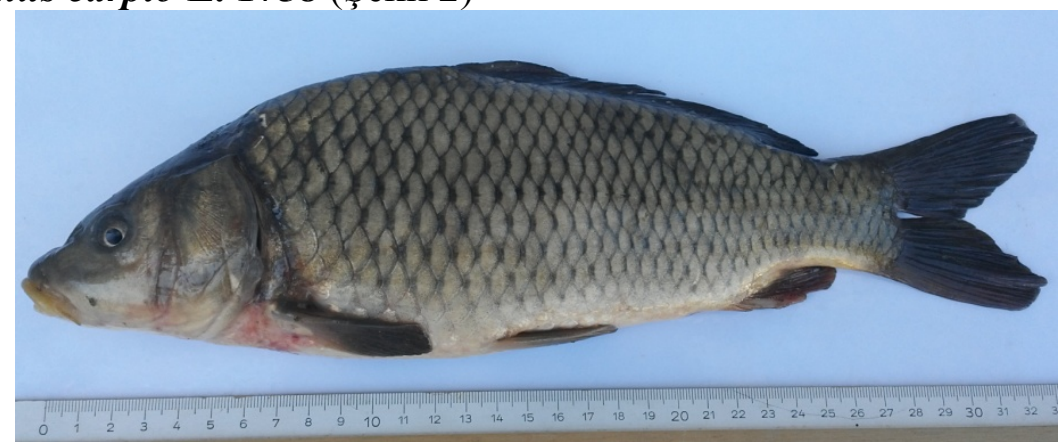

Şekil 2. Cyprinus carpio

$\mathrm{N}: 43$, SB: $330.77 \pm 78.59 \mathrm{~mm}(245-440), \mathrm{SB} / \mathrm{VY}: 2.72$ (2.21-3.54), SB/BB: 4.47 (3.646.47), BB/GÇ: 6.53 (4.56-8.50), BB/IM: 1.89 (1.48-2.43), İM/GÇ: 3.49 (2.69-5.00), D: III-IV 15-21, A: II-III 5-7, P: I 14-18, V: I-II 7-8, L. lat.: 33-39, Omur say1s1: 36-37

\subsubsection{Carassius gibelio (Bloch, 1782) (Şekil 3)}

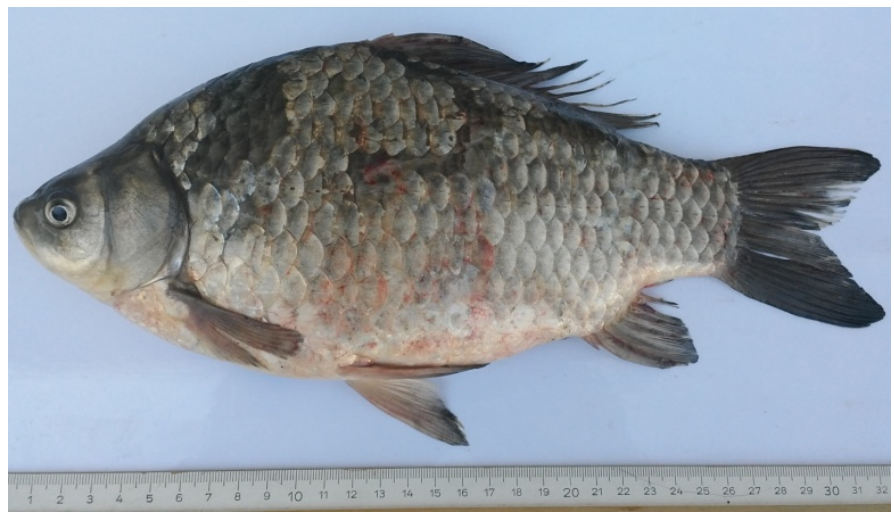

Şekil 3. Carassius gibelio 
$\mathrm{N}: 42$, SB: $260.12 \pm 79.83 \mathrm{~mm}$ (165-343), SB/VY: 2.42 (2.32-2.68), SB/BB: 3.83 (3.534.02), BB/GÇ: 4.79 (3.73-5.76), BB/IM: 2.02 (1.86-2.16), İM/GÇ: 2.37 (2.00-2.78), L. lat.: 31-33, D: IV 17-19, A: II-III 5-7, P: I 15-16, V: II 8, Omur sayıs1: 30-31

\subsubsection{Tinca tinca (L. 1758) (Şekil 4)}

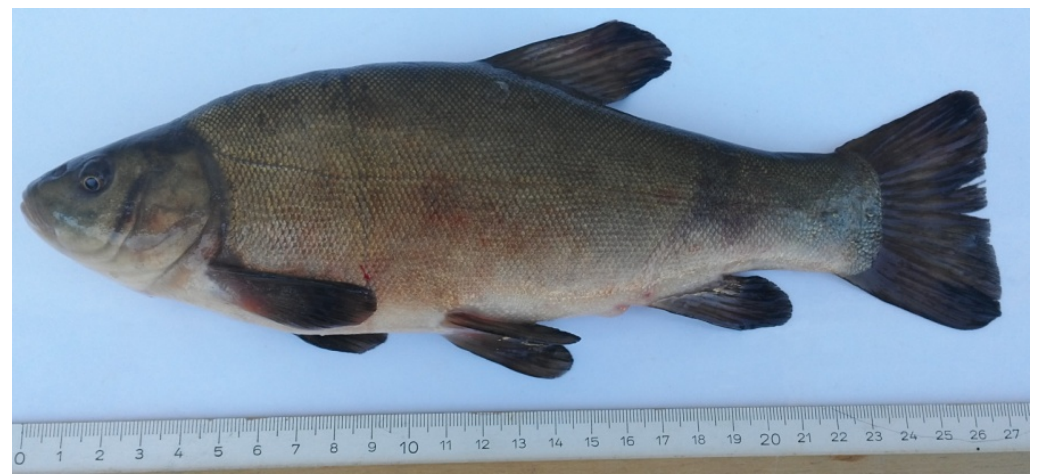

Şekil 4. Tinca tinca

$\mathrm{N}: 31, \mathrm{SB}: 246.16 \pm 26.54 \mathrm{~mm}(200-325)$, SB/VY: 3.12 (2.50-3.56), SB/BB: 4.20 (3.577.71), BB/GÇ: 6.30 (3.50-8.42), BB/IM: 2.05 (1.17-2.50), İM/GÇ: 3.09 (2.30-4.28), L. lat.: 91-109, D: III-IV 8-10, A: III 7-9, P: I 15-18, V: I-II 8-10, Omur say1s1: 39-41

\subsubsection{Alburnus escherichii Steindachner, 1897 (Şekil 5)}

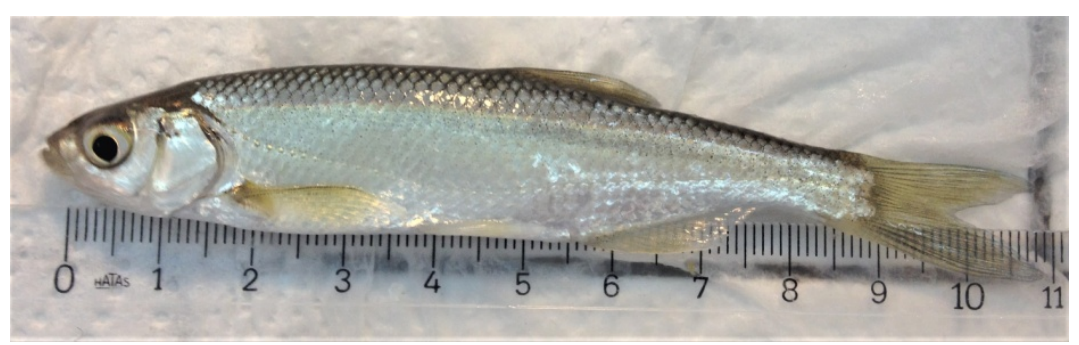

Şekil 5. Alburnus escherichii

$\mathrm{N}: 42$, SB: $87.01 \pm 0.87 \mathrm{~mm}$ (70-101), SB/VY: 4.54227 (3.50-6.21), SB/BB: 4.03 (1.874.59), BB/GÇ: 3.67 (2.50-6.84), BB/İM: 3.61 (3.32-4.29), İM/GÇ: 0.67 (0.59-0.83), L. lat.: 46-54, D: II 7-9, A: II-III 9-13, P: I 11-14, V: I 6-8, Omur say1s1: 35-37 
3.1.5. Pseudorasbora parva (Temminck \& Schlegel, 1846) (Şekil 6)

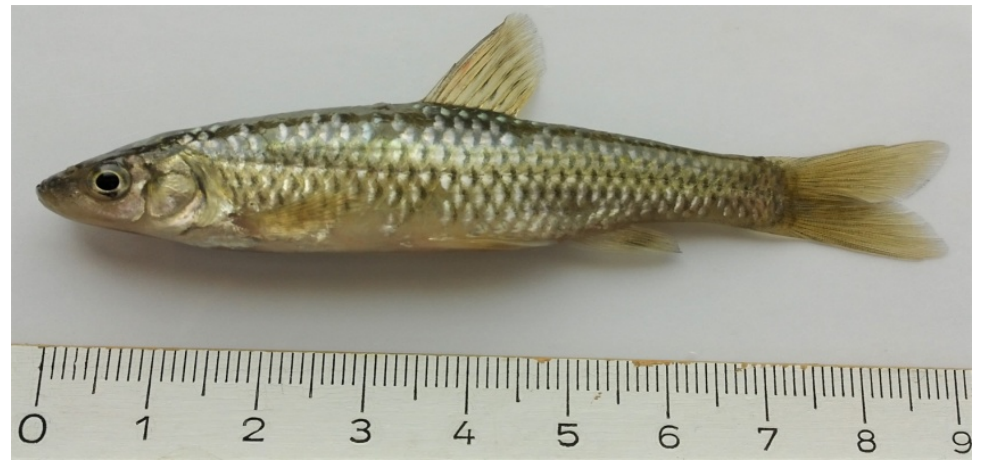

Şekil 6. Pseudorasbora parva

$\mathrm{N}: 74, \mathrm{SB}: 51.28 \pm 5.11 \mathrm{~mm}$ (44-67), SB/VY: 4.35 (3.31-5.56), SB/BB: 4.06 (2.88-4.89), BB/GÇ: 4.27 (3.25-5.87), BB/IM: 2.48 (1.71-3.50), İM/GÇ: 1.76 (1.04-2.92), L. lat.: 34- 39, D: I-III 5-7, A: II-III 5-7, P: I 8-11, V: I-II 6-8, Omur sayıs1: 33-38

\section{Order: Atheriniformes}

Familya: Atherinidae

\subsubsection{Atherina boyeri Risso, 1810 (Şekil 7)}

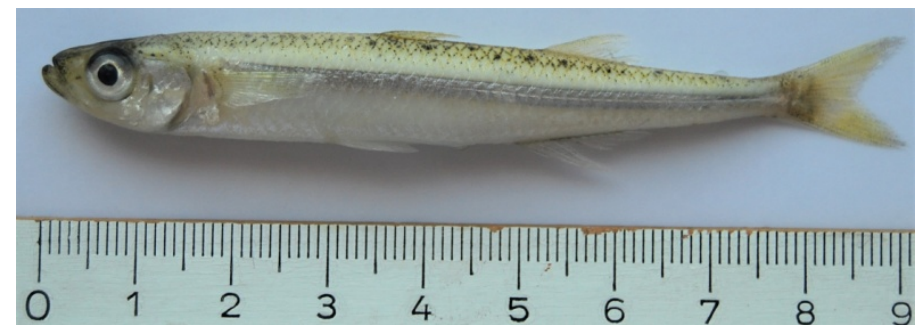

Şekil 7. Atherina boyeri

$\mathrm{N}: 68, \mathrm{SB}: 76.03 \pm 1.11 \mathrm{~mm}(53-90), \mathrm{SB} / \mathrm{VY}: 5.04$ (3.53-6.08), SB/BB: 4.02 (2.94-4.82), BB/GÇ: 2.95 (2.28-3.60), BB/İM: 3.83 (3.02-4.61), İM/GÇ: 0.78 (0.71-0.83), L. lat.: 46-50, D1: VI-VIII, D2: II 10-12, A: II 11-13, P: I-II 11-14, V: I-II 5-7, Omur say1s1: $47-49$

Order: Isospondyli

Familya: Esocidae 


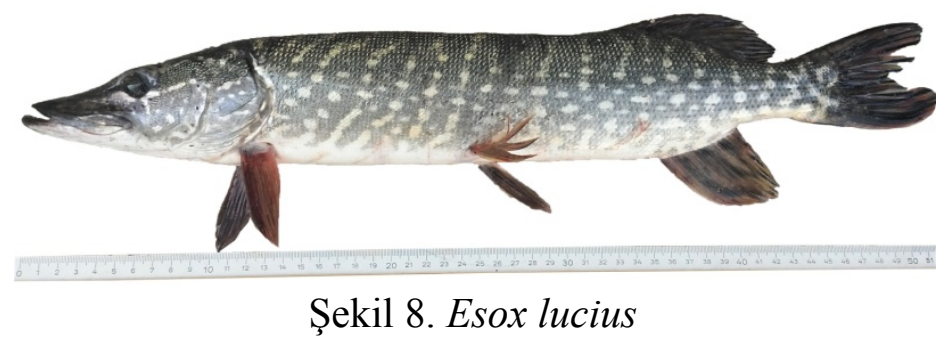

$\mathrm{N}: 32$, SB: $406.25 \pm 3.68 \mathrm{~mm}$ (355-498), SB/VY: 5.86 (5.07-6.71), SB/BB: 3.51 (3.174.09), BB/GÇ: 8.82 (5.79-11.50), BB/IM: 3.96 (3.14-5.37), İM/GÇ: 2.25 (1.57-3.50), L. lat.: 115-130, D: VI-IX 13-16, A: IV-VII 12-15, P: I 13-16, V: I-II 8-10, Omur sayıs1: 59.

\section{Tartışma ve sonuç}

$\mathrm{Bu}$ araştırma ile Mogan Gölü balık faunasının belirlenmesi amaçlanmıştır. Ekonomik önemi olan C. carpio'nun farklı su sistemlerindeki bazı diyagnostik özelikleri ile ilgili yapılan araştırmalarda; Uzunçayır Baraj Gölü'nde D: III-IV 20-21, A: III 5-6, P: I-II 1418, V: II 8-9 [2]; Apolyont Gölü'nde D: III-IV 18-20, A: II-III 5-6, P: I 14-17, V: I-II 78, L. lat.: 35-38 [21]; Çakmak Baraj Gölü'nde D: IV 19-20, V: II 8, A: III 5, P: I 15, L. lat.: 38-39 [22]; Çamlıgöze Baraj Gölü'nde D: III 18-20, A: III 5-6, P: I 14-16, V: II 78, L. lat.: 34-38 [23]; İkizcetepeler Baraj Gölü'nde D: III-IV 18-21, A: III 5-6, P: I 1516, V: II 7, L. lat.: 36-39 [24]; Seyhan Baraj Gölü'nde D: III 17-21, A: III 5, P: I 13-14, V: II 6-8, L. lat.: 30-37 [25]; Büyük Menderes Nehri'nde D: III 18-20, A: II-III 5-6, L. lat.: 36-39, Omur sayısı: 36-37 [26] olarak bildirmişlerdir. Bu çalışmada bulunan L. lat. pul sayısı ve pektoral yüzgeç 1şın sayılarının literatürde bildirilen değerlerden farklı olduğu görülmüştür. $\mathrm{Bu}$ farklılıklarda habitatların fizikokimyasal koşulları ile populasyondaki genetiksel çeşitliliğin etkisi olduğu düşünülebilir. Diğer diyagnostik özelliklerin ise benzer sonuçlar içerdiği belirlenmiştir.

C. gibelio, gerek vücut şekli gerekse dorsal ve anal yüzgeçlerin 3. basit 1şınının testere dişi şeklinde olması nedeniyle $C$. carpio ile benzerlik göstermektedir. Ancak, ağızda da bıyık olmaması, farinks dişlerinin tek sıralı olması ile sazandan kolayca ayırt edilir. Dorsal yüzgecin serbest kenarı içbükey-düz, dorsal ve anal yüzgecin son basit ışının kuvvetli bir şekilde tırtıklı olduğu bildirilmiştir [20]. Diyagnostik özellikleri Topçam Baraj Gölü'nde D: III-IV/15-18, A: II-III/6, P: I/16-18, V: II/8-9; L. lat: 30-32 [27]; Bat1 ve Orta Anadolu, Güney Marmara, Trakya ve Batı Karadeniz bölgesinin bazı iç sularında D: III/16-20, A: II-III/5-7, L. lat: 26-31 [28]; İkizcetepeler Baraj Gölü'nde D: III-IV 15-19 A: II-III 5-6 P: I 12-14 V: I-II 7-8 L. lat.: 27-31 [29] ; Trakya Bölgesi'nin çeşitli tatlı sularında D: III-IV 15-19; A: III-IV 4-5, L. lat.: 29-32 [30]; Miliç Irmağı'nda D: IV-V 16-19, V: II 8-9, A: III 5-6, P: I 13-15, L. lat.: 30-33 [31]; Çakmak Baraj Gölü'nde D: IV-V 15-20, V: II 7-8, A: III 5, P: I 14-19, L. lat.: 30-32 [22]; Gaga Gölü'nde D: III-IV 18-21, V: II 7-9, A: II III 5-6, P: I 15-20, L. lat.: 29-31 [32]; Suat Uğurlu Baraj Gölü'nde D: III 17-18, A: III 5, P: I 15-18, V: II 8, L. lat.: 30-31 [33] olarak bildirmektedirler. Mogan Gölü populasyonu ile diğer çalışmalarda bildirilen 
meristik ve metrik karakterlerin, lokalitelerin ekolojik özelliklerine bağlı olarak varyasyonlar gösterdiği belirlenmiştir.

Türkiye içsularında çok geniş bir dağılıma sahip olan T. tinca'nın farklı su sistemlerinde diyagnostik özellikleri verilmektedir. Seyhan Baraj Gölü’nden D: III 8, A: III 6-7, P: I 11-15, V: II 9, L. lat: 95-98 [25]; İznik Gölü'nden D: III-IV 8-9, A: III-IV 6-7, L. lat: 101-111 [34]; Bafra Balık Gölleri, Karaboğaz Lagünü, Liman Lagünü, Simenit-Akgöl Lagünü'nden D: IV 9, A: III-IV 7-8, P: I 17-18, V: II 9, L. lat.: 98-102 [35]; Eğirdir, Gölcük ve Beyşehir Gölleri'nden D: III-IV 8-9, A: III 6-8, P: I 15-16, V: I 8-9, L. lat.: 88-99 [36]; Batı Karadeniz Bölgesi tatlı sularından D: III 8, A: III 7, P: I 15, V: I 9 L. lat.: 97 [37] olarak bildirmektedirler. Bu çalışmada tespit edilen yanal çizgideki pul sayısı, dorsal yüzgeç ve anal yüzgeç ışın sayıları dışında diğer özelliklerin ise literatür ile benzerlik gösterdiği belirlenmiştir.

A. escherichii Anadolu iç sularından Sakarya ve Kızılırmak havzalarında dağılım gösteren bir türdür [5]. Morfometrik ve meristik özellikleri Porsuk Çayı'ndan (Sakarya), D: III 8, A: III 12-14, P: I 16, V: I 8-9, L. lat.: 48-50 olarak belirtilmiştir [38]. Bu sonuçlar ile Mogan Gölü populasyonundaki değerler benzerlik göstermektedir.

Biyoçeşitliliği ve sucul yaşamı olumsuz etkileyen istilacı bir tür olarak bilinen $P$. parva' nın Anadolu'daki hızlı yayılışı, Türkiye'nin zengin tatlısu balık faunası için bir tehdit olarak kabul edilebilir [39]. Bu türün diyagnostik özellikleri; Dipsiz-Çine Çayı'nda D: II-III 7-8, A: III 6, P: I 8-12, V: I 7-8, L. lat.: 35-38 [40]; Samsun ili içsu kaynaklarında D: III 7, V: II 7, A: III 6, P: I 12-13 L. lat.: 36-38 [41]; Gölcük Gölü'nden D: III 7-8, A: III 6-7, P: I 12-14, V: 7-8 L. lat.: 34-36 [36]; Antalya Körfezi'ne dökülen akarsulardan D: III 7-8, A: III 6-7, L. lat.: 34-37, Omur sayıs1: 30-31 değerlerini [42] bildirilmektedirler. Farklı lokaliteler ile Mogan Gölü populasyonu arasında özellikle L. lat. ve pektoral yüzgeçteki ışın sayıları arasında farklılıklar belirlenmiştir.

Mogan Gölü'ne nasıl girdiği belli olmayan A. boyeri geniş adaptasyon yeteneğine sahip bir tür olup morfolojik ve biyolojik karakterleri açısından bölgesel çeşitlilik gösterir [43]. A. boyeri ile ilgili farklı su sistemlerinde yapılan araştırma sonuçlarında; İznik Gölü'nde D1: VI-X, D2: II 10-13, A: I 12-16, P: 13-16, L. lat.: 43-49 [44]; Firat ve Asi nehir havzasindan D1: VI-VII, D2: II 12-13, A: II 13-15, P: II 12-13, V: I 5 [45]; Fethiye Körfezi'nden D1: VI-IX, D2: I 9-15, A: I 12-18, L. lat.: 39-49 [46] olarak bildirilmektedir. Mogan Gölü A boyeri populasyonunda elde edilen değerler İznik Gölü, Fırat ve Asi nehir havzasındaki sonuçlarla benzerlik gösterdiği, Fethiye Körfezi'ndeki populasyonun L. lat. pul sayısı aralığ 1 ile farklılık gösterdiği görülmüsstür. $\mathrm{Bu}$ farkların habitatların biyotik ve abiyotik koşullarındaki değişimlerden ve türün ekolojik hoşgörüsünün geniş olmasından kaynaklandığı düşünülmektedir.

E. lucius 'un farklı çalışmalarda diyagnostik özellikleri verilmektedir. Ladik Gölü'nden D: VI-VIII 15-16, A: VI-VII 13-14, L. lat.: 120-134 [47]; Büyükçekmece Baraj Gölü'nden D: VI-X 14-15, P: I 14-15, V: II 9-11, A: VI-VIII 11-14, L. lat.: 120-122 [48]; Büyük Menderes Nehri'nden D: V 14, A: IV 15, L. lat.: 128 [26] şeklinde rapor edilmiştir. $\mathrm{Bu}$ çalışmada saptanan diyagnostik özellikler ile farklı araştırıcıların tespitleri arasında çoğunlukla benzerlik olduğu gözlenmiştir. 
Balık türleri farklı habitatlardaki populasyonlarında çevresel faktörlerin etkisi altında kaldığından diyagnostik özelliklerinde değişimler gösterebilmektedir. Bu populasyonlar arasındaki farklılıkları saptamada morfometrik ve meristik özelliklerden yararlanılmaktadır. Ülkemizde son yıllarda balık türlerinin morfometrik ve meristik özellikleri ile ilgili çok sayıda çalışma yapılmakta olsa da, çevresel faktörler bu canlılar üzerinde önemli etkilere sebep olduğundan farklı habitatlardaki değişimler sürekli olarak izlenmelidir.

$\mathrm{Bu}$ amaçla yerli, egzotik ve istilacı türlerin bir arada bulunduğu Mogan Gölü’nde balık faunası araştırılmıştır.

Tip lokalitesi Avrupa olan C. carpio Türkiye'de çok geniş dağılım gösteren bir türdür. Daha çok doğal gölleri, havuzları ve dibi çamurlu suları severler. Omnivor olduklarından çok geniş bir beslenme rejimine sahiptirler [3]. Türkiye'de doğal sulara aşılanarak kültür balıkçılığında kullanılmaktadır. Carassius türlerinin ise tatlı, acı, tuzlu, oksijen seviyesi düşük kirli sularda yaşayabildikleri [49], aşırı çoğalma eğilimi ile ortamda baskın tür haline gelebildikleri belirtilmektedir [28]. Asya kökenli olan $C$. gibelio, çeşitli yollarla Avrupa ülkeleri ve Türkiye'de hızla yayılan bir türdür. Farklı ve baskın bir üreme aktivitesi gösterdikleri için, doğal balık populasyonları için zararlı bir tür olarak bilinmektedir [50].

Yakın Doğu ve Sibirya kökenli olan T. tinca Avrupa, Batı Asya ve Hazar Denizi'nde yayılmış ve Türkiye'ye kuzeyden girmiştir. 19. yüzyıldan beri, Orta Avrupa'da havuz balığı olarak yetiştirilmektedir. Zemin materyalini sürekli olarak karıştırdıklarından mineralizasyonda önemli rol oynarlar. Özellikle bu balıkların, sazan yetiştirme havuzları ile bahçe havuzlarının temizlenmesinde kullanıldığı bildirilmektedir [51].

1970'li yıllardan itibaren bazı doğal göl ve baraj göllerimize aşılanan A. escherichii'nin yayılış alanı gün geçtikçe artmakta olup, özellikle Anadolu iç sularında etkin bir sivrisinek larva-pupa predatörü olduğu belirtilmektedir [52]. Araştırmalar sırasındaki gözlemlerimize göre $A$. escherichii'nin amatör balıkçılar tarafından canlı yem olarak kullanıldığı için pek çok sulak alana bu yolla taşınmış olabileceği de düşünülmektedir.

Biyoçeşitliliği ve sucul yaşamı olumsuz etkileyen istilacı bir tür olarak bilinen $P$. parva' nın Anadolu'daki hızlı yayılışı, Türkiye'nin zengin tatlı su balık faunası için bir tehdit olarak kabul edilebilir [39]. Bu türün yayılmasının kontrol altına alınabilmesi için hayat döngüsüne, doğal ortamlarında ve laboratuvar koşullarındaki verilerinin elde edilmesi ve incelenmesi gerekmektedir.

Mogan Gölü'ne giriş şekli belli olmayan A. boyeri geniş adaptasyon yeteneğine sahip bir tür olup, morfolojik ve biyolojik karakterleri açısından bölgesel çeşitlilik gösterir [43]. A. boyeri, öyrihalin bir tür olup, kıyı habitatlarda, estuarin sularda, lagünlerde, tuzlu bataklıklarda, sı̆̆ acı sularda ve iç sularda yaşamakta ve diğer balık türlerine göre firsatçı beslenme özelliği göstermektedir [44]. A. boyeri ülkemiz iç sularında hızla yayılarak biyolojik kirliliğe ve doğal ekosistemlerde geri dönüşümü olmayan etkilere neden olmaktadır. Yayıldığı habitatlardaki adaptasyon özelliği ve diğer türler ile rekabetinde başarılı olabilecek özelliklere sahip olduğu bilinmektedir. İstilacı olan bu türle mücadele etmek için farklı su sistemlerindeki biyo-ekolojik özelliklerinin çok iyi bilinmesi büyük önem taşımaktadır. 
E. lucius ise Avrupa'da çok bilinen bir tatlı su balığı olup, ülkemiz sularında da yaygın olarak bulunmakta ve ticari değeri olduğu için üzerinde av baskısı yoğun türlerden biridir. Çeşitli sucul habitatlarda yaşayan balık populasyonlarının kontrol altına alınmasında kullanılmaktadır. Balık türlerinin sistematik, biyolojik ve ekolojik yönden değerlendirilebilmeleri için bulunduğu lokalitelerdeki bilimsel çalışmalardan elde edilen verilere gereksinim bulunmaktadır. Ayrıca türün bulunduğu habitatta doğal yollardan mı, yoksa farklı yollardan mı sucul alana yerleştiği bilgileri, hem filogenetik ilişkilerinin tespitinde hem de türün yayılışının belirlenmesinde katkı sağlayacaktır [53].

Bu çalışmada elde edilen sonuçlara göre Mogan Gölü'nde 3 familyaya ait 7 balık türü bulunduğu belirlenmiştir. Çalışmada, literatürde kaydı bildirilen Silurus glanis'e rastlanmamış olması [7] ve balıkçılık faaliyeti ile uğraşan şahısların da bu yöndeki gözlemleri bu türün gölde tamamen tükenmiş olabileceğini düşündürmektedir.

Mogan Gölü balık faunasını oluşturan türlerin ve stoklarının geleceği için biyo-ekolojik izleme çalışmalarının yapılması yörenin biyoçeşitliliği açısından yararlı olacaktır.

\section{Kaynaklar}

[1] Vatandoust, S., Abdoli, A., Anvarifar, H. ve Mousavi-Sabet, H., Morphometric and meristic characteristics and morphological fario (Pisces: Salmonidae) along the southern Caspian Sea basin, European Journal of Zoological Research, 3, 2, 56-65, (2014).

[2] Çoban, M. Z., Gündüz, F., Yüksel, F., Demirol, F., Yıldırım, T. ve Kurtoğlu, M., Uzunçayır Baraj Gölü (Tunceli) balık faunası, Yunus Araştırma Bülteni, 2, 3544, (2013).

[3] Geldiay, R. ve Balık, S., Türkiye Tatlısu Balıkları, 644, Ege Üniversitesi Su Ürünleri Fakültesi Yayınları, No: 46, Ders Kitabı Dizini No: 16, V. Baskı, İzmir, (2007).

[4] Çiçek, E., Birecikligil Sungur, S. ve Fricke, R., Addenda and errata of: Freshwater fishes of Turkey: a revised and updated annotated checklist, Fish Taxa, 1, 2, 116-117, (2016).

[5] Çiçek, E., Birecikligil, S.S. ve Fricke, R., Freshwater fishes of Turkey: A revised and updated annotated checklist, Biharean Biologist, 9, 2, 141-157, (2015).

[6] Sandsten, H., Beklioglu, M. ve İnce, Ö., Effects of waterfowl, large fish and periphyton on the spring growth of Potamogeton pectinatus L. in Lake Mogan Turkey, Hydrobiologia, 537, 1-3, 239-248, (2005).

[7] Anonim, Mogan Gölü Havzası biyolojik zenginlikleri ve ekolojik yönetim planı, Çevre Bakanlığı Özel Çevre Koruma Kurumu Başkanlığı, 167, Ankara, (2002).

[8] Hamalosmanoğlu, M. ve Kuru, M., Mogan Gölü'nde (Ankara) yaşayan kadife balığının (Tinca tinca L., 1758) karyotip analizi ve idiogrami, Turkish Journal of Veterinary and Animal Sciences, 28, 1, 143-147, (2004).

[9] Ergönül, M. B. ve Altındağ, A., The occurrence and dynamics of Ligula intestinalis in its cyprinid fish host, tench, Tinca tinca, in Mogan Lake (Ankara, Turkey), Veterinarni Medicina Praha, 50, 12, 537-542, (2005).

[10] Benzer, S., Arslan, H., Uzel, N., Gül, A., Y1lmaz, M., Concentrations of metals in water, sediment and tissues of Cyprinus carpio L., 1758 from Mogan Lake (Turkey), Iranian Journal of Fisheries Sciences, 12, 1, 45-55, (2013). 
[11] Gül, G., Benli, A. Ç. K. ve Erkoç, F., Mogan Gölü’ndeki bazı balık türlerinde vitellogenin proteininin elektroforetik karşılaştırılması, Electrophoretic comparison of vitellogenin protein in some fish species in Mogan Lake, Ege Journal of Fisheries and Aquatic Sciences, 33, 2, 151-156, (2016).

[12] Yılmaz, M., Gül, A., Şahin, N. ve Benzer, S., Mogan Gölü'nde yaşayan turna balığ (Esox lucius (L. 1758))'nın beslenme biyolojisi, Gazi Üniversitesi Gazi Eğitim Fakültesi Dergisi, 30, 1, 203-218, (2010).

[13] Benzer, S. ve Gül, A., Growth properties of Alburnus orontis Sauvage, 1882 in Mogan Lake, Proceedings of International Symposium on Fisheries and Aquatic Sciences FABA, 371, 3-5 November, Antalya, (2016).

[14] Benzer, S., Saylar, Ö., Düzel, S., Gül, G., Y1lmaz, M. ve Gül, A., Some biochemical blood parameters in Mogan Lake economic fish species, Proceedings of ICOCEE-Cappadocia, 421, May 20-23, Nevşehir, (2015).

[15] Gül, A., Yılmaz, M., Benzer, S., Saylar, Ö. ve Uzel, N., Mogan Gölü egzotik balık türlerinden Atherina boyeri Risso 1810' nin morfometrik ve meristik özellikleri. II Balıklandırma ve Rezervuar Yönetimi Sempozyum özetleri, 193, 20-22 Mayıs Eğirdir, Isparta, (2015).

[16] Kuru, M., Türkiye Tatlısu Balıkları Kataloğu, 73, Hacettepe Üniversitesi Fen Fakültesi Yayınları, Yardımcı Kitaplar Dizisi 1, Ankara, (1980).

[17] Bogutskaya, N. G., Contribution to the knowledge of leuciscine fishes of Asia Minor. Part 2. An annotated check-list of leuciscine fishes (Leuciscinae, Cyprinidae) of Turkey with descriptions of a new species and two new subspecies, Mitteilungen aus dem hamburgischen Zoologischen Museum und Institut, 94, 161-186, (1997).

[18] Kottelat, M., Fishes of Laos, 198, WHT Publications Ltd., Colombo 5, Sri Lanka, (2001).

[19] Kottelat, M. ve Freyhof, J., 646, Handbook of European freshwater fishes, Publications Kottelat, Cornol and Freyhof, Berlin, (2007).

[20] Yerli, S. V., Mangıt, F., Emiroğlu, Ö., Yeğen, V., Uysal, R., Ünlü, E., Alp, A., Buhan, E., Yıldırım, T. ve Zengin, M., Distribution of Invasive Carassius gibelio (Bloch, 1782) (Teleostei: Cyprinidae) in Turkey, Turkish Journal of Fisheries and Aquatic Sciences, 14, 2, 581-590, (2014).

[21] Berber, S., Hüseyin, Şaşı,, Topkara, E. T. ve Cengiz, Ö., Apolyont Gölü (Bursa) balık faunasının belirlenmesi, Turkish Journal of Aquatic Sciences, 26, 1, 2755, (2011).

[22] Uğurlu, S. ve Polat, N., Çakmak Baraj Gölü (Samsun) balık faunası, Fırat Üniversitesi Fen ve Mühendislik Bilimleri Dergisi, 19, 4, 443-448, (2007a).

[23] Dirican, S. ve Çilek, S., Identification of fish species of Çamligöze Dam Lake, Sivas, Turkey, African Journal of Agricultural Research, 7, 45, 6022-6026, (2012).

[24] Torcu Koç, H., Türker Çakır, D. ve Ulunehir, G., An investigation in fish fauna İkizcetepeler Dam Lake (Balıkesir) Turkey, Journal of Applied Biological Sciences, 2, 2, 63-67, (2008).

[25] Ergüden, S. A. ve Göksu, M. Z. L., The fish fauna of the Seyhan Dam Lake (Adana), Journal of FisheriesSciences.com, 6, 1, 39-52, (2012).

[26] Güçlü, S. S., Küçük, F., Ertan, Ö. O. ve Güçlü, Z., The fish fauna of the Büyük Menderes River (Turkey): Taxonomic and zoogeographic features, Turkish Journal of Fisheries and Aquatic Sciences, 13, 4, 685-698, (2013). 
[27] Şaşı, H. ve Balık, S., The investigation of fish species in Topçam Dam Lake (Çine-Aydın), Süleyman Demirel Üniversitesi Eğirdir Su Ürünleri Fakültesi Dergisi, 9, 46-50, (2003).

[28] İlhan, A., Balık, S., Sarı, H. M. ve Ustaoğlu, M. R., Batı ve Orta Anadolu, Güney Marmara, Trakya ve Batı Karadeniz Bölgeleri iç sularındaki Carassius (Cyprinidae, Pisces) türleri ve dağılımları, Ege Üniversitesi Su Ürünleri Dergisi, 22, 3-4, 343-346, (2005).

[29] Erdoğan, Z., Torcu Koç, H., Güngör, S. ve Ulunehir, G., Age, growth and reproductive properties of an invasive species Carassius gibelio (Bloch, 1782) (Cyprinidae) in the İkizcetepeler Dam Lake (Balikesir), Turkey, Periodicum Biologorum, 116, 3, 285-291, (2014).

[30] Özuluğ, M., Meriç, N. ve Freyhof, J., The distribution of Carassius gibelio (Bloch, 1782) (Teleostei: Cyprinidae) in Thrace (Turkey), Zoology in the Middle East, 31, 1, 63-66, (2004).

[31] Uğurlu, S. ve Polat, N., Miliç Irmağı (Terme, Samsun) balık faunası, Ege Üniversitesi Su Ürünleri Dergisi, 23, 3-4, 441-444, (2006).

[32] Dönel, K. E. ve Yilmaz, E., The fish fauna of Gaga Lake (Ordu-Turkey) and identification of four species by morphometric characteristics, Journal of Maritime and Marine Sciences, 2, 2, 8-19, (2016).

[33] Uğurlu, S. ve Polat, N., Suat Uğurlu Baraj Gölü ile Terice ve Göksu Deresi balıkları (Ayvacık-Samsun), Süleyman Demirel Üniversitesi Eğirdir Su Ürünleri Fakülttesi Dergisi, 1, 2, 27-37, (2005).

[34] Özuluğ, M., Altun, Ö. ve Meriç, N., On the fish fauna of Lake İznik (Turkey), Turkish Journal of Zoology, 29, 4, 371-375, (2005).

[35] Uğurlu, S., Polat, N. ve Kandemir, Ş., Kızılırmak ve Yeşilırmak deltalarındaki (Samsun) lagün göllerinin balık faunası, Journal of Fisheries Sciences.com, 2, 3, 475-483, (2008).

[36] Yeğen, V., Balık, S., Bostan, H., Uysal, R. ve Bilçen, E., Göller bölgesindeki bazı göl ve baraj göllerinin balık faunalarının son durumu, 1. Ulusal Balıklandırma ve Rezervuar Yönetimi Sempozyumu, 129-139, 7-9 Şubat, Antalya, (2006).

[37] İlhan, A., Batı Karadeniz bölgesi tatlısu balıklarının taksonomik ve ekolojik özelliklerinin araştırılması, Doktora Tezi, Ege Üniversitesi, Fen Bilimleri Enstitüsü, İzmir, (2006).

[38] Anonim, Anadolu incibalığı (Alburnus nasreddini) tür eylem planı, 101, T.C. Orman ve Su İşleri Bakanlığı, Doğa Koruma ve Milli Parklar Genel Müdürlüğü, V. Bölge Müdürlüğü, Afyonkarahisar Şube Müdürlüğü, (2015).

[39] Ekmekçi, F. G. ve Kırankaya, Ş. G., Distribution of an invasive fish species, Pseudorasbora parva (Temminck \& Schlegel, 1846) in Turkey, Turkish Journal of Zoology, 30, 3, 329-334, (2006).

[40] Barlas, M. ve Dirican, S., The fish fauna of the Dipsiz-Çine (Muğla-Aydın) Stream, Gazi University Journal of Science, 17, 3, 35-48, (2004).

[41] Uğurlu, S. ve Polat, N., Samsun ili tatlı su kaynaklarında yaşayan egzotik balık türleri, Journal of FisheriesSciences.com, 1, 3, 139-151, (2007b).

[42] Küçük, F. ve İkiz, R., Antalya Körfezi'ne dökülen akarsuların balık faunası, Ege Üniversitesi Su Ürünleri Dergisi, 21, 3-4, 287-294, (2004).

[43] Çetinkaya, S., Uysal, R., Yeğen, V., Cesur, M. ve Bostan, H., The growth characteristics of sand smelt (Atherina boyeri, Risso 1810) in Lake İznik (Türkiye), Turkish Journal of Fisheries and Aquatic Sciences, 11, 4, 641-648, (2011). 
[44] Altun, Ö., Gümüşbalığı (Atherina boyeri Risso, 1810) populasyonlarında gözlemlenen morfolojik varyasyonlar, Turkish Journal of Zoology, 23, 3, 911918, (1999).

[45] Birecikligil, S. ve Çiçek, E., Gaziantep ili sınırları içindeki Fırat ve Asi Havzası akarsuları balık faunası, Biyoloji Bilimleri Araştırma Dergisi, 4, 2, 29-34, (2011).

[46] Doğan, T., Fethiye Körfezi (Muğla, Türkiye)'nin balık faunası, Yüksek Lisans Tezi, Adnan Menderes Üniversitesi, Fen Bilimleri Enstitüsü, (2007).

[47] Uğurlu, S., Polat, N. ve Kandemir, Ş., Changes in the Lake Ladik fish community (1972-2004) and ichthyofauna of its inlet and outlet streams (Samsun, Turkey), Turkish Journal of Zoology, 33, 4, 393-401, (2009).

[48] Özuluğ, M., A taxonomic study on the fish in the basin of Büyükçekmece Dam Lake, Turkish Journal of Zoology, 23, 439-451, (1999).

[49] Kesici, E., Bafa Gölü Tabiat Parkı'nda belirlenen istilacı balık türü Carassius auratus gibelio (Bloch, 1782) (Gümüşi Havuz Balığı), Tabiat ve İnsan, 46, 11$16,(2012)$.

[50] İnnal, D. ve Erk'akan, F., Effects of exotic and translocated fish species in the inland waters of Turkey, Reviews in Fish Biology and Fisheries, 16, 1, 39-50, (2006).

[51] Michaels, V. K., Carp Farming, 200, The Dorset Press, Dorchester, (1988).

[52] Ege, M. ve Boşgelmez, A., Alburnus orontis'in Anopheles maculipennis ve Culex pipiens üzerindeki predatörlük etkinliği, Ulusal Su Günleri, 105-114, 6-8 Ekim, İzmir, (2004).

[53] Yılmaz, E., Elekçi Irmağı (Fatsa/Ordu) Balık Faunası, Süleyman Demirel Üniversitesi Journal of Science (e-Journal), 11, 2, 1-12, (2016). 